\title{
Ударно-хвильова терапія в лікуванні несправжніх суглобів
}

\author{
В. М. Левенець, М. М. Риган, А. О. Веремій
}

\author{
Центр спортивної травматології Національного університету \\ фізичного виховання і спорту України
}

\begin{abstract}
Резюме. Рассмотрены показания к применению ударно-волновой терапии (УВТ) в лечении псевдоартрозов, а также процедуру УВТ при лечении ложных суставов. Поданы результаты проведения данного метода терапии, осуществленной в центре спортивной травматологии. Ключевые слова: псевдоартроз, показания УВТ, результаты лечения.
\end{abstract}

Summary. Indications for the use of shock wave therapy(SWT) in the treatment of pseudoarthrosis as well as the routine of SWT treatment of false joints are discussed. The results of the use of this method of treatment in the center of sports traumatology are presented.

Keywords: pseudarthrosis, indications for SWT, results of the treatment.

Постановка проблеми. Багато років проблема лікування несправжніх суглобів була актуальною у травматології-ортопедії. Окремим питанням у другій половині XX ст. було присвячено безліч робіт, кількість яких навіть неможливо підрахувати. Лише за останні 30 років було надруковано 27 монографій та навчальних посібників, захищено 21 дисертаційну роботу, у тому числі - шість докторських.

Кінець XX ст. позначився детальним висвітленням питань, що стосувались стимуляції репаративного остеогенезу при псевдоартрозах, інструментальної діагностики кісткової пластики та черезкісткового остеосинтезу, впливу фрізіотерапевтичних і бальнеологічних методів на процес зрощення.

Не можна не відмітити ряд пропозицій до класифрікації, внесених відомими вченими $[1,2]$. В одній із наукових праць [3] автори звернули увагу на розподіл несправжніх суглобів, $з$ огляду на порушення трофіки, на гіперпластичний і гіпопластичний. Слід зазначити, що $є$ ще й нормопластичний псевдоартроз.

Віддаючи належне успіхам у лікуванні несправжніх суглобів, слід відмітити, що в цілому до сьогодні проблема остаточно не вирішена. Спірними залишились показання до хірургічних методів лікування залежно від форми та стану кісткових уламків, суперечливими - найбільш ефективні і разом із тим доступні малоінвазивні та надійні методи лікування залежно від виду, ступеня дегенеративних змін уламків, стану оточуючих тканин.

Завдяки роботам багатьох учених $[4,7,9]$ опрацювання і втілення в практику ортопедії i спортивної медицини методу ударно-хвильової терапії (УХТ) в лікуванні несправжніх суглобів дає можливість повернутися знову до цієї актуальної проблеми.

Актуальність проблеми полягає в розробці показань до використання методів УХТ у вигляді сфрокусованих і радіальних хвиль залежно від стану кісткових уламків, щільності енергії, частоти, енергетичного рівня та глибини проникнення хвиль.

Мета дослідження - розробка показань до використання сфокусованих хвиль у лікуванні псевдоартрозів кісток, у тому числі у спортсменів залежно від стану кісткової структури і форми уламків, а також стану оточуючих тканин, виду хвиль та фрізичних параметрів.

Матеріали та методи дослідження. Було обстежено 37 пацієнтів із несправжніми суглобами, у тому числі 11 спортсменів. Обстеження проводили за допомогою клінічного, лабораторного, ортопедичного, рентгенографрічного методів та візуальної аналогової шкали (ВАШ).

За терміном, який пройшов після виявлення псевдоартрозів, пацієнтів розподіляли таким чином: $1-1,5$ року - 29 пацієнтів; 2,5 року п'ять осіб; 6-7 років - три пацієнти.

За локалізацією: у 26 пацієнтів відмічено псевдоартроз гомілки (дев'ять спортсменів), у трьох - плечової кістки (один спортсмен), у семи - стегнова кістка (один - верхня третина, три - діасріз, три - нижня третина) та в одного спортсмена виявлено псевдоартроз ключиці.

Для лікування псевдоартрозів застосовували апарат MINILITH SL-1 (рис. 1). Для запобігання втрат енергії і профрілактики можливої гематоми подушку джерела ударних хвиль і шкіру пацієнта у місці дотику з'єднували без яких-небудь повітряних включень між ними. 3 цієї самої причини пацієнтам, для лікування яких необхідно більше 


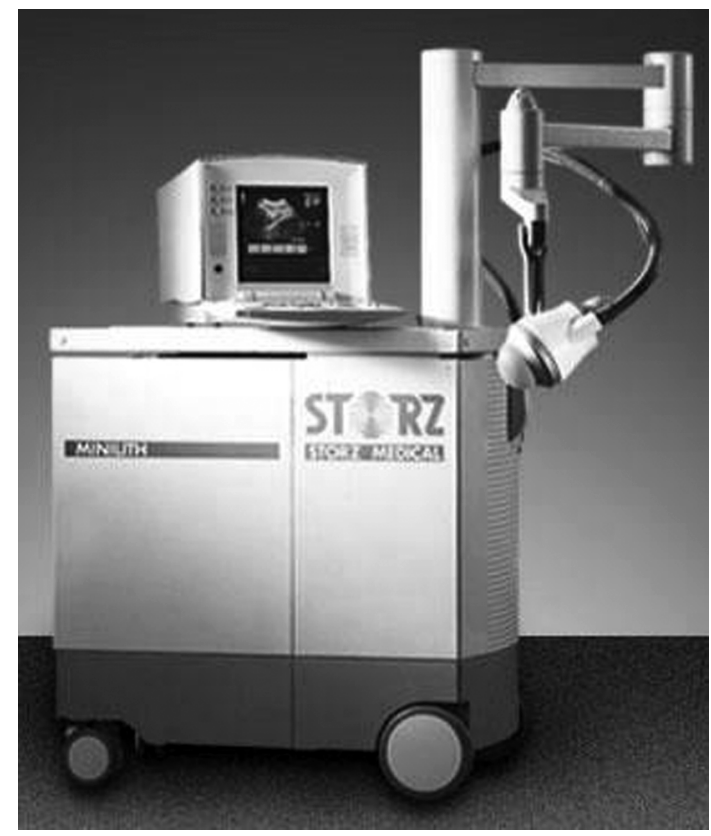

Рисунок 1 - Апарат MINILITH SL-1

високих енергетичних хвиль, потрібно видаляти волосяний покрив у ділянці дотику подушки до тіла. Система ударних хвиль забезпечена фоокусуючим пристроєм, вона дозволяє зосередити енергію на визначеній локальній ділянці. Цей момент свідчить про те, що ударні хвилі без ушкодження оточуючих тканин переносять повну дозу енергії, тим більше, що є причини вважати енергію і щільність їі потоку вирішальним фрактором, який визначає успіх лікування.

Апарат MINILITH SL-1 має систему ультразвукової локалізації, що забезпечує контроль цільової ділянки і запобігання зайвого радіаційного опромінення. Характерним позитивним моментом $€$ поширення ультразвукових хвиль в одному напрямку з ударними хвилями.

Дані спеціальної літератури свідчать, що під час лікування несправжніх суглобів ударними хвилями виникають мікроушкодження міжуламкової рубцевої тканини з наступною проліферацією та фрормуванням остеоїдних клітин, а під час наступних сеансів за рахунок остеостимуляції - і клітин кісткової тканини [4]. Ці положення і рекомендації наукового комітету фрізики і технології Німецького міжнародного товариства екстракорпоральної ударно-хвильовї терапії (DIGES) дали нам право застосовувати в умовах клініки метод УХT в лікуванні псевдоартрозів.

Пізніше одужання пов'язували 3 регенеративними процесами, які організм самостійно запускає після цілеспрямованого мікроруйнування. Але це лише припущення. Останніми роками проходять наукові дослідження, спрямовані на з'ясування механізмів дії ударних хвиль на живі клітини.

Під час лікування несправжніх суглобів ми використовували високоенергетичну УХТ зі щільністю енергії 0,6-0,8 мДж • мм² , частотою 4 Гц та 3000 ударами за один сеанс. Як правило, всього пацієнти проходили п'ять сеансів. Лише двом пацієнтам із псевдоартрозом діафізу стегнової кістки окрім основного курсу було додатково виконано ще чотири сеанси.

Результати дослідження та їх обговорення. Перед початком лікування пацієнта необхідно ознайомити з процедурою, а також попередити про можливість «переносити» біль певної сили. Для цього потрібно змінювати енергетичний рівень і частоту, а у випадках поганої переносимості болю починати знижувати частоту. Слід при цьому пам'ятати, що енергетичний рівень певної сили забезпечує необхідну глибину проникнення, але безкінечно його не можна зменшувати, тому що це призведе до зниження ефективності процедури.

Аналіз лікування пацієнтів із псевдоартрозами показав, що найкращі результати одержано у випадках гіпертрофрічних і нормотрофрічних несправжніх суглобів. Наявність металевої внутрішньокісткової або накісткової пластини не $є$ протипоказанням для УХТ. Тому ми вважаємо, що показаннями для застосування ударних хвиль можуть бути:

1) сповільнена консолідація переломів;

2) нормотрофрічні та гіпертрофрічні псевдоартрози, підтверджені рентгенологічно;

3) негативні результати після оперативного втручання;

4) важливим $€$ розмір щілини між кістковими уламками, що не повинен перевищувати 4-5 мм.

Протипоказаннями для УХТ $\epsilon$ гіпопластичні псевдоартрози; наявність остеомієлітичного процесу, запальні процеси шкіри у зоні несправжнього суглоба, наявність щілини між кістковими уламками більше 4-5 мм. Головним протипоказанням слід вважати вади кліткової тканини та значні порушення біомеханічної осі кінцівки.

Перші 15 пацієнтів одержували УХТ без знеболювання, наступні сім одержували місцеве знеболювання, п'яти пацієнтам було застосовано інгаляційний ненаркотичний аналгетик швидкої дії Пентрокс® (метоксифлуран). Це потужний анестетик, який пацієнт може приймати самостійно (але під контролем лікаря) для 5-10 вдихань. Препарат не має побічної дії, призначений для пацієнтів усіх вікових груп. Доведено його серцево-судинну та респіраторну безпеку i 
стабільність. Головне - це можливість самостійного застосування і самоконтролю болю.

Десяти пацієнтам, які відмовились від знеболювання, лікарі змушені були дещо зменшити енергію тиску.

Спостереження за пацієнтами засвідчили гарну переносимість больових відчуттів. Шість пацієнтів відмітили слабкий біль після першої процедури, який поступово зник протягом 6-10 год. У п'яти пацієнтів під час виконання перших сеансів було допущено деякі помилки (нещільне прилягання подушки до шкіри, наявність волосяного покриву), у результаті відмічено на місці ударних хвиль почервоніння, невеликий набряк та ділянки петехіальних судинних реакцій. Побічні дії не вплинули на позитивний кінцевий результат.

Як приклад наведемо резюме з історії хвороби пацієнтів, яким було проведено УХТ.

Спортсмен-легкоатлет 27 років звернувся в Центр спортивної травматології Національного університету фрізичного виховання і спорту України 6.XII.2006 р. 3 діагнозом несправжній суглоб правої гомілки на межі середньої та нижньої третини. Травму отримано 11.09.2005 р. внаслідок дорожньо-транспортної пригоди. У місцевій лікарні пацієнту запропонували скелетне витягнення, що і провели 11.09.2005 р. 7.11.2005 р. йому наклали гіпсову пов'язку до нижньої третини стегна, яку зняли 25.01.2006 р. та дозволили ходити; рентгенографрію не проводили. Пацієнт ходив 20-25 днів і скаржився на нестабільність - гомілка «не тримала» навантаження. В лікарні знову без рентгенографрії наклали гіпсову пов'язку і пацієнт перейшов на режим «ходьби за допомогою милиць». Пов'язка була знята, і в обласній лікарні йому запропонували оперативне лікування. Пацієнт не дав згоду і звернувся в Центр, де йому було встановлено діагноз і дано пораду до УХТ. Враховуючи наявність запальних шкірних висипань, пацієнту було запропоновано з'явитися для лікування в грудні. При зверненні в Центр він пересувався за допомогою милиць, а клінічно в зоні нижньої третини правої гомілки відчував безболісну рухомість. Наступати на праву ногу пацієнт не може. Перед початком лікування за допомогою ударних хвиль йому зробили задню шину з Скоч Каст. Рентгенологічно в нього визначається порушення структури кісток гомілки на межі середньої і нижньої третин, згладженість кінців великогомілкової кістки, закриття кістково-мозкового каналу між її уламками (рис. 2). Пацієнт у процесі лікування кінцівку не навантажував.

Через п'ять місяців після закінчення п'ятого сеансу ударно-хвильової терапії пацієнт пересу-

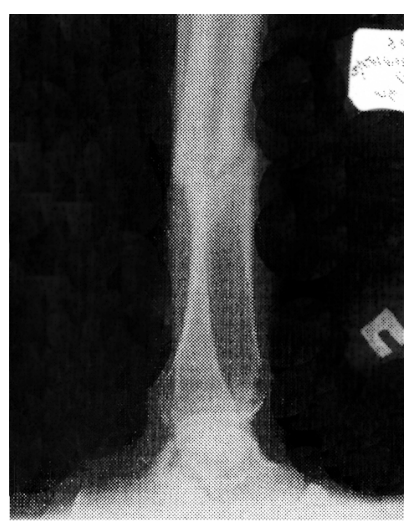

a

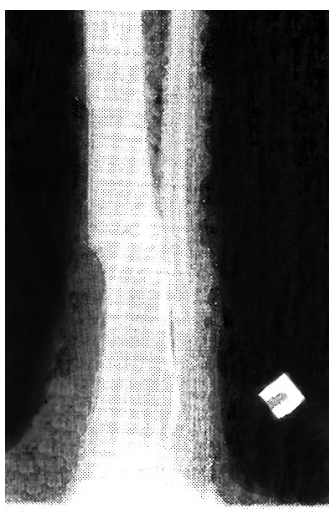

6
Рисунок 2 - Ознаки несправжнього суглоба великогомілкової кістки:

а) наявність щілини між уламками, закриття кістковомозкового каналу (порожнини), б) склероз замикаючих кісткових пластинок

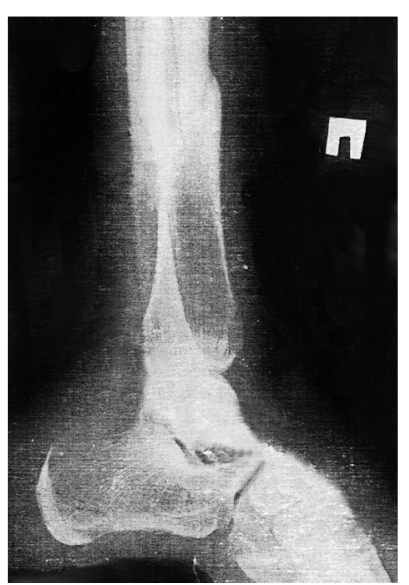

a

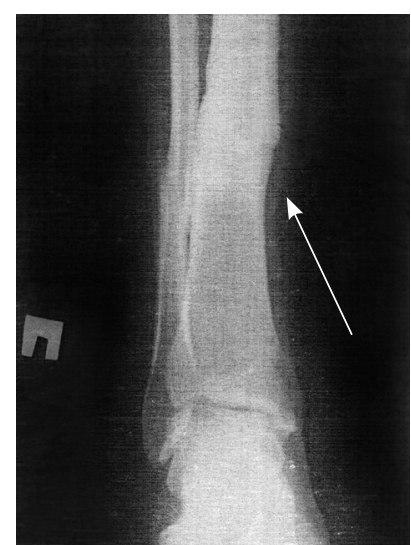

6
Рисунок 3 - Ліквідація несправжнього суглоба: а) відновлення цілості кортикальної пластинки; б) ліквідація щілини між уламками

вається, навантажуючи кінцівку. Клінічно - рухомість на місці псевдоартрозу зникла. Рентгенологічно - консолідований несправжній суглоб (рис. 3).

Пацієнтка С-а М.В., 69 років, домогосподарка, 4 листопада 2004 р. впала, в результаті чого отримала підвертлюговий перелом правого стегна. Каретою швидкої допомоги її доставлено у лікарню швидкої допомоги, де було прооперовано: виконано остеосинтез кутовою пластинкою. Через два місяці пацієнтка почала давати навантаження і до лікаря не зверталася. Приблизно півтора року вона пересувалася, повністю навантажуючи оперовану кінцівку, а через 2,5 року відчула нестійкість у суглобі. Пацієнтка звернулась у лікарню, де їй провели обстеження i на рентгенограмі виявили щілину між уламками 4-5 мм (рис. 4). 


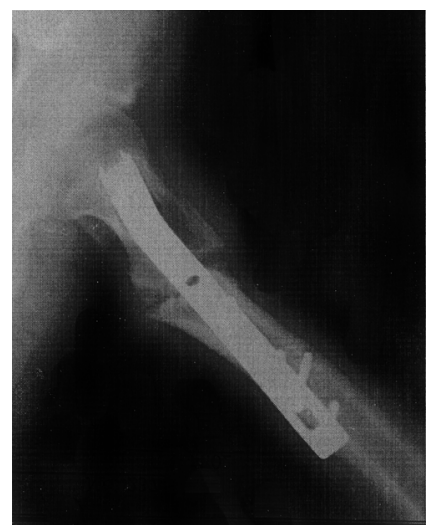

a

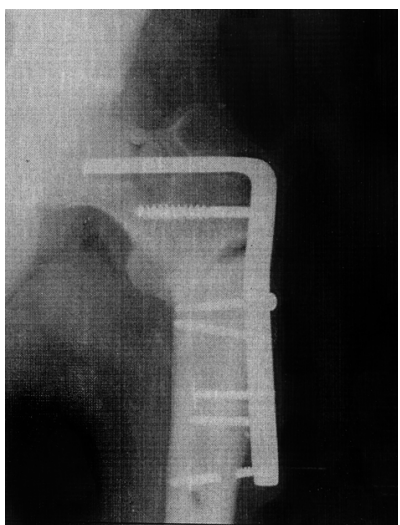

б

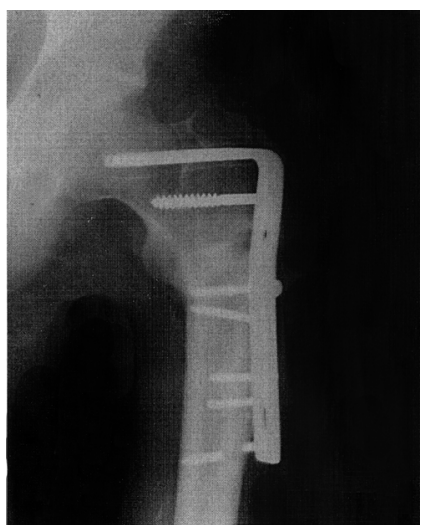

a

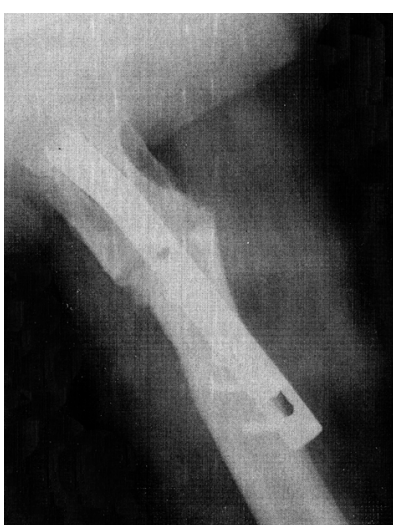

6

Рисунок 4 - Рентгенограма пацієнтки С-ої М.В.: а) сформований несправжній суглоб із наявністю щілини між кістковими уламками; б) внаслідок невірно розташованої пластини уламки знаходяться в стані зміщення

У Центрі після обстеження запропонували пацієнтці вирішити проблему без операції за допомогою сфокусованих хвиль апаратом MINILITH SL-1. Враховуючи значний масив м'яких тканин, лікування проводили при тиску 10 мПа й енергетичному режимі 0,9 мДж мм $^{2}$ і кількості ударів 3000, кількість сеансів збільшено до шести. Хвора знаходилась під наглядом лікарів Центру, які постійно контролювали ії̈ клінічний стан. Через сім місяців під час контрольного огляду скарг не було пред'явлено; жінка пересувається без сторонньої допомоги, трохи накульгує на праву ногу. Рентгенологічно - щілина між уламками не визначається, заповнена кістковою тканиною, за щільністю дещо меншою ніж здорова тканина (рис. 5).

Ці приклади свідчать про те, що фокусовані ударні хвилі передаються на невелику ділянку і можуть точно бути націлені в зону інтересів $\mathrm{ROI}$ (region interest), внаслідок чого максимальна енергія досягає потрібної ділянки під шкірою [5, $6]$.

Біологічна реакція, викликана цими хвилями, може бути як прямою, так і побічною. Енергія ударних хвиль, які поглинаються тканинами, веде до виникнення розтягувальних сил, що стимулюють видалення фрактора росту та підвищену неоваскуляризацію оброблених тканин. Це і $\epsilon$ пряма дія ударних хвиль [8].

Разом із тим ударні хвилі викликають і побічні дії, одна з яких відома як утворення кавітаційних пухирців, котрі оцінюються як джерело потенційної енергії. Ця точка зору визнається не всіма вченими.

Якщо ударні хвилі повторюються, то вони викликають стимуляцію розширення тканин, скорочення, стикання і, в кінцевому результаті,

Рисунок 5 - Рентгенограма пацієнтки С-ої після закінчення фокусованої ударно-хвильової терапії: а) щілина між уламками зникла; б) псевдоартроз ліквідовано

їх руйнування, що веде до виділення додаткової енергії в оброблені тканини. Ця додаткова енергія викликає руйнування і крововиливи в клітини сполучної тканини, котра розташована між уламками. Через шість днів, які $\epsilon$ проміжком між окремими сеансами, замість сполучнотканинних клітин починає формуватися остеоїдна тканина.

Наступний сеанс також викликає руйнування клітин, але вже не сполучнотканинних, а остеоїдних, і знову крововилив стимулює новий поштовх росту остеоїдних клітин. Ця додаткова енергія викликає і стимулює біологічну реакцію, або так званий «побічний ефект» [5].

Останні дослідження значно розширили розуміння окремих питань впливу ударних хвиль на біологічні тканини. Роботами багатьох авторів було доведено підвищення неоваскуляризації, прискорене виділення фрактора росту, рекрутування стовбурових клітин, невральне інгібіювання, що дає позитивний ефект у лікуванні псевдоартрозів.

\section{Висновки.}

1. Показаннями для застосування УХТ при несправжніх суглобах слід вважати нормопластичні та гіперпластичні форми кісткових уламків.

2. УХТ слід використовувати за наявності щілини між кістковими уламками не більше 4-5 мм. Оптимальним варіантом слід вважати щілину 3 мм.

3. Процедуру УХТ для лікування псевдоартрозів доцільно виконувати сфокусованими ударними хвилями, що забезпечує необхідну глибину проникнення, пряму та побічну біологічну реакцію.

4. На період лікування несправжніх суглобів необхідно не допускати прямого безпосереднього навантаження кінцівки. 
5. За три-п'ять місяців до початку УХТ небажано призначати фрізіотерапевтичні та бальнео-

\section{Література}

1. БогданоВ Ф. Р. О хирургическом лечении больных с осложненными ложными суставами и десектами большеберцовой кости / Ф. Р. Богданов, И. Г. Антонюк // Ортопедия, травматол. и протезир. - 1965. - № 3. - С. 9-14.

2. Скляренко E. T. К вопросу классификации и костнопластического лечения больных с ложными суставами / Е. Т. Скляренко, И. Г. Антонюк // Ортопедия, травматол. и протезир. - К.: Здоров'я, 1983. - С. 33-37.

3. Шумада И. В. Компрессионно-дистракционный остеосинтез при ложных суставах длинных трубчатых костей / И. В. Шумада, Ю. С. Жила, О.И.Рыбачук // Вестн. хирургии. - 1976. - № 4. - С. 90-94.

4. Dahmen G. P. Extrakorporale Stosswellentherapie (ESWA) zur Behandlung von knochennahen weichtellschmerzen. Indikation, Technikund vorleufige Ergebnisse / / Deutsche Gesellschatt für stosswellenlithotripsie (ed): Konsensus / G. P. Dahmen, V. C. Nam, L. Meiss. - Tübingen: Attemp to Verlag. - 1993. - P. 143-148.

5. Gerdesmeyer L. Extracorporeal Shockwave Therapy. Clinical results, technologies, basics / L. Gerdesmeyer, L. Wel // Data trace Publiching. - 2007. - ISBN: 978-1-570-578.

6. Ogden J. A. Principles of shock wave therapy / J. A. Ogden et al. // Clin. Orthop. Relat Res. - 2001:17:348-58.

7. Schleberger $R$. Non-invasive treatment of long-bone pseudarthrosis by shock waves (ESWL) / R. Schleberger, T. Senge // Arch. Orthop. Trauma Surg. - 1992. - 111. P. 224-227.

8. Schleberger R. Extracorporeal shock wave therapy (ESWT) method analysis and suggestion of a prospective study design - consensus report. In Chaussy et al. (eds) / R. Schleberger et al. // High Energy Shock Waves in Medicine. - Stuttgart: Thieme pages, 1997 - P. 108-111.

9. Valchanou V. D. High energy shock waves in the treatment of delayed and nonunion of fractures/V. D. Valchanou, P. Michailov // Int. Orthopaedy. - 1991:15:181-184. логічні процедури, після закінчення УХT, за наявності показань, їх доцільно застосовувати.

\section{References}

1. Bogdanov F. R. On the surgical treatment of patients with complicated false joints and tibial defects / F. R. Bogdanov, I.G. Antoniuk // Orthopaedics, traumatology and prosthetics. - 1965. - № 3. - P. 9-14.

2. Skliarenko E. T. On the classification and osteoplastic treatment of patients with false joints / E. T. Skliarenko, I. G. Antoniuk // Orthopaedics, traumatology and prosthetics. - Kyiv: Zdorovia, 1983. - P. 33-37.

3. Shumada I. V. Compression-distraction osteosynthesis in false joints of long bones / I. V. Shumada, Yu. S. Zhyla, O. I. Rybachuk // Vestnik khirurgii (Bulletin of surgery). 1976. - № 4. - P. 90-94.

4. Dahmen G. P. Extrakorporale Stosswellentherapie (ESWA) zur Behandlung von knochennahen weichtellschmerzen. Indikation, Technikund vorleufige Ergebnisse / / Deutsche Gesellschatt for stosswellenlithotripsie (ed): Konsensus / G. P. Dahmen, V. C. Nam, L. Meiss. - Tübingen: Attempto Verlag. - 1993. - P. 143-148.

5. Gerdesmeyer L. Extracorporeal shockwave therapy. Clinical results, technologies, basics / L. Gerdesmeyer, L. Well // Data trace Publiching. - 2007. - ISBN: 978-1-570-578.

6. Ogden J. A. Principles of shock wave therapy / J. A. Ogden et al. // Clin. Orthop. Relat Res. - 2001:17:348-58.

7. Schleberger $R$. Non-invasive treatment of long-bone pseudarthrosis by shock waves (ESWL) / R. Schleberger, T. Senge / / Arch. Orthop. Trauma Surg. - 1992. - 111. P. 224-227.

8. Schleberger R. Extracorporeal shock wave therapy (ESWT) method analysis and suggestion of a prospective study design - consensus report. In Chaussy et al. (eds) / R. Schleberger et al. // High energy shock waves in medicine. - Stuttgart: Thieme, 1997 - P. 108-111.

9. Valchanou V. D. High energy shock waves in the treatment of delayed and nonunion of fractures / V. D. Valchanou, P. Michailov // Int. Orthop. - 1991. - Vol. 15. - P. 181-184.

Надійшла 15.01.2013 